\title{
Growth rate and heterozygosity in the plaice, Pleuronectes platessa
}

\author{
B. J. McAndrew, \\ R. D. Ward $\dagger$ and \\ J. A. Beardmore
}

\author{
Department of Genetics, \\ University College of Swansea, \\ Singleton Park, Swansea, SA2 8PP, U.K.
}

Samples of young plaice were examined to see if there was any relationship between growth rate and individual heterozygosity, screened across five polymorphic enzyme loci (Pgm-1, Ada, Mdh-2, Pgi-2, $\alpha G p d h-1)$. Two out of 46 samples showed a significant negative correlation between growth rate and multi-locus heterozygosity; none showed a significant positive correlation. There was no overall tendency to negative or positive correlations. The largest sample $(N=689)$ showed no relationship between multi-locus heterozygosity and growth rate, although one of the five loci, $\alpha G p d h-1$, showed a significant positive correlation. The only significant correlation in the next largest sample $(N=$ 248) was between multi-locus heterozygosity and growth rate, and that was negative. Fish of intermediate growth rate were not significantly different in heterozygosity from faster or slower growing fish. There was no relationship between variability in growth rate and multi-locus heterozygosity. These findings are discussed in the context of similar surveys from other species, and the conclusion drawn that the universality of a positive relationship between growth rate and multi-locus heterozygosity remains to be established.

\section{INTRODUCTION}

In recent years, a number of papers have been published examining the relationship between growth rate and individual heterozygosity. A variety of plant and animal species have been investigated, for a limited number of polymorphic loci, and the majority of these studies point to the existence of a positive correlation (Mitton and Grant, 1984).

The first study associating individual multilocus heterozygosity and growth rate came from Singh and Zouros (1978) and Zouros et al., (1980), working on the American oyster, Crassostrea virginica. Positive associations have subsequently been reported from natural populations of some other bivalves: Mytilus edulis (Koehn and Gaffney, 1984, although the relationship changed in older samples from the same cohort, Diehl and Koehn, 1985), Mulinia lateralis (Garton et al., 1984), and for one of two populations of Macoma balthica

Present addresses:

* Institute of Aquaculture, University of Stirling, Stirling, FK9 4LA, U.K.

† Department of Human Sciences, Environmental Biology Unit, Loughborough University, Loughborough, Leicestershire, LE11 3TU, U.K.
(Green et al., 1983). However, Foltz and Zouros (1984) and Beaumont et al. (1985) were unable to detect any such relationship in two species of scallops, Placopecten magellanicus and Pecten maximus respectively. Furthermore, Beaumont et al. (1983) also observed no effect of multi-locus heterozygosity on growth rate in 1 year old sibships of $M$. edulis reared in the laboratory.

Positive correlations between heterozygosity and length were reported in 5 out of 7 populations of young larvae of the salamander, Ambystoma tigrinum (Pierce and Mitton, 1982), and laboratory experiments suggested that the length differences were due to differential growth rates. Older larvae did not show the relationship. King (1985) found little evidence of a correlation between heterozygosity and growth rate in the herring, Clupea harengus, although there was a positive correlation between multi-locus heterozygosity and length. Beacham and Withler (1985) could not detect a difference in growth rate between homozygous and heterozygous pink salmon, Oncorhynchus gorbuscha. Cothran et al. (1983) observed a positive relationship between individual heterozygosity and foetal growth rate in the white-tailed deer, Odocoileus virginianus. Bottini et al. (1979) had earlier described a similar relationship in man, 
although Ward et al. (1985) were unable to detect such an effect in a larger study of human birth weight, albeit from a different population.

In plants, heterozygosity and growth rate was found to be associated in quaking aspen, Populus tremuloides (Mitton and Grant, 1980), but this species reproduces primarily vegetatively and the population has a clonal structure. Significant positive correlations were found in 3 of 8 stands of the pitch pine, Pinus rigida, but one stand showed a significant negative correlation (Ledig et al., 1983). In neither ponderosa pine (Pinus ponderosa) nor lodgepole pine (Pinus contorta) is heterozygosity related to mean growth rate of mature trees (Grant et al., 1982; Knowles and Mitton, 1980; Knowles and Grant, 1981; Mitton, 1983; Mitton et al., 1981).

If there is a general relationship between growth rate and individual heterozygosity, as determined by screening between 4 and 10 polymorphic loci (most of the above studies falling into this range), this has clear theoretical implications for the current neutralist-selectionist controversy, and important practical implications for those engaged in animal and plant breeding. Yet the generality of the relationship seems to us not clearly established, and, as is so often the case, more work is required on further species.

In this paper, we examine the relationship between growth rate and multiple and single locus heterozygosity in a fish, the plaice. Pleuronectes platessa. In order to do this, we have restricted ourselves to examination of data from young plaice (less than 460 days of age), for which we have numerous large samples of known age.

\section{MATERIALS AND METHODS}

Young fish were collected by pushnetting in shallow water on the sandy beaches of South Wales, with by far the greatest number coming from Pendine Sands, Carmarthen Bay. Other beaches were sampled at Swansea Bay and Oxwich Bay. These fish are spawned off Trevose Head, Cornwall (Simpson, 1959), and the young fish are carried by ocean currents to the nursery beaches where they were sampled. Spawning takes place in late January, February, and March, probably peaking around mid-February (Simpson, 1959). In our calculations of fish age, we have assumed a nominal fertilisation date of February 14 for each year. Cushing (1969) has estimated the standard error of the mean date of spawning in the North Sea as $2 \cdot 5$ days.

Fish were weighed to the nearest $0.01 \mathrm{~g}$ and measured in length (from tip of head to tip of caudal fin) to the nearest $\mathrm{mm}$. Each fish was then screened electrophoretically for five polymorphic loci, whose products were detectable in muscle tissue, and, depending on the number of heterozygous loci, assigned a heterozygosity score of 0 , $1,2,3,4$, or 5 . These loci were phosphoglucomutase-1 (Pgm-1), adenosine deaminase (Ada), malate dehydrogenase-2 (Mdh-2), phosphoglucose isomerase-2 (Pgi-2) and glycerophosphate dehydrogenase ( $\alpha G p d h-1)$. Details of gene and genotype frequencies and electrophoretic procedures followed are given in Ward and Beardmore (1977). Cross-tabulations and some of the statistical tests were performed using the SPSS computer package (Nie et al., 1975).

\section{RESULTS}

In this analysis, we have chosen length as the parameter by which to estimate growth rate: weight is subject to greater short-term variation. Forty-six samples of young fish were analysed, 29 from Pendine, nine from Swansea, and eight from Oxwich, providing a total of 3964 fish. Information on sampling dates, ages, sample sizes, mean lengths and mean numbers of loci heterozygous is presented in table 1.

Fig. 1 shows graphically the age-related changes in mean length of the two most thoroughly sampled cohorts, Pendine 1975 and Pendine 1977. The youngest "O" group fish (those in their first year of life) were collected at the end of May or beginning of June. Growth continued through the summer months, ceased in the winter, and resumed in the spring. Patterns of growth were similar in the two cohorts, although the 1977 cohort was on average somewhat smaller than that of 1975 . Density of O-group fish, estimated from catch/effort returns, was probably greater in 1977 , and increased competition may have retarded growth slightly in this cohort.

Several tests were carried out to uncover any possible relationships between growth rate and heterozygosity.

First, both the Pearson (parametric) and Spearman (non-parametric) correlation coefficients were calculated for each sample. These two sets of values were generally very similar to each other; the Pearson values are given in table 1 . It can be seen that of the 46 samples, 20 had a positive value for $r$ and 26 a negative value. This is not significantly different from a random distribution ( $X=0.78, P=0.38$ ), and hence this analysis fails 
Table 1 Sample ages, numbers, sizes, heterozygosities, and correlation coefficients between heterozygosity score and Length

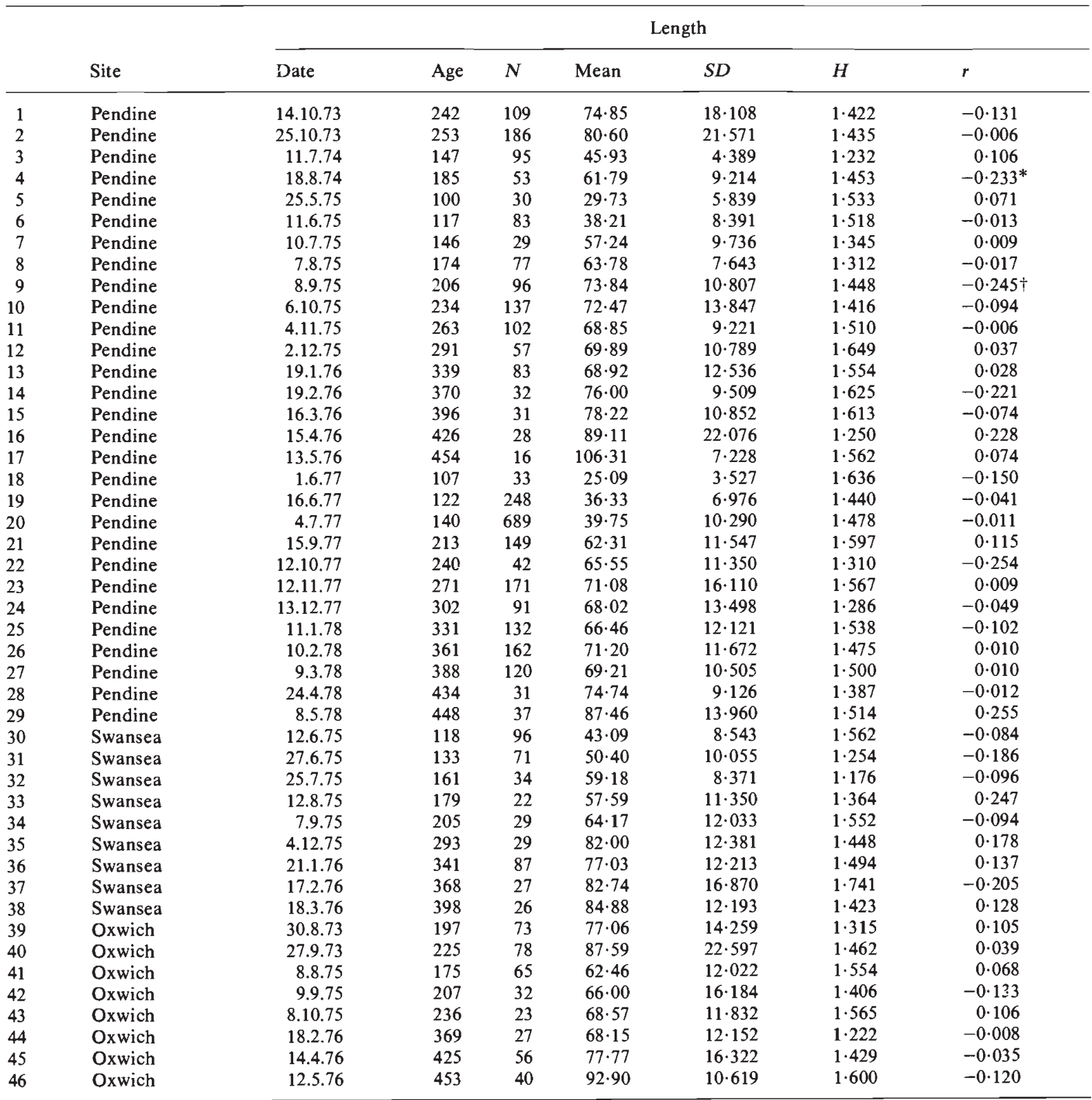

Note: $H$ is the mean number of heterozygous loci per fish. $r$ has $N-2 \mathrm{df} .{ }^{*} P=0.05-0.01, \dagger P=0.01-0.001$.

to support the hypothesis of a positive relationship between growth rate and heterozygosity. Only two of the correlation coefficients are significantly different from zero, and both of these are negative.

Secondly, the mean lengths of fish having a heterozygosity score of $0,1,2,3,4$ and 5 were calculated for each of the 46 samples (see appendix), and the data analysed in one of two ways. In method $\mathrm{A}$, each of the heterozygosity classes in each sample was assigned a rank of $1,2,3,4$ or 5. The class with the smallest mean length was assigned a rank of 1 , the next shortest class in that sample assigned a value of 2 , and so on. The very small number of fish heterozygous at all five loci was ignored. These data were then subjected to an analysis of variance by ranks (Meddis, 1984), using a specific test that there should be a monotonically ascending trend of ranks from the homozygous 


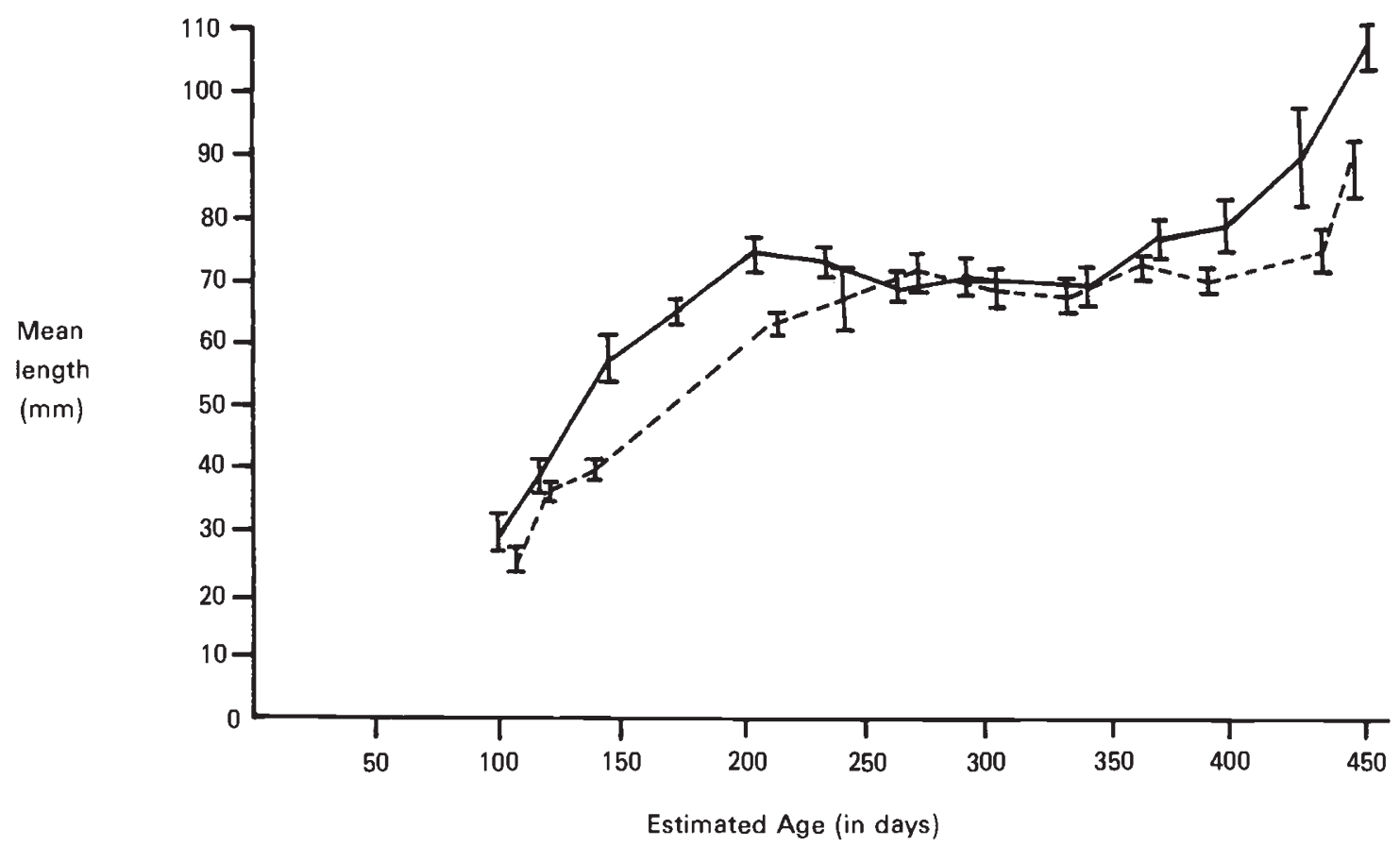

Figure 1 Mean length of fish plotted against estimated age in days. Solid lines (__ ) indicate the 1975 cohort, dashed lines (-----) the 1977 cohort. 95 per cent confidence limits are given.

fish to those with a heterozygosity score of 4 . The results of this test are given in table 2 . It can be seen that there is no evidence to support the view that increasing multi-locus heterozygosity is associated with growth rate.

In method B, the small numbers of fish having scores of 4 and 5 were pooled with those having scores of 3 , and if the mean length of fish with a particular heterozygosity score $(0,1,2$ or $3+)$ was greater than the overall mean length of that sample, that group was assigned to a "+" category, if less, to a "-" category. If heterozygosity is associated with increased growth rate, then groups of fish having heterozygosity scores of 2 and $3+$ should

Table 2 Rank analysis of the relationship between heterozygosity class and mean length

\begin{tabular}{lllll}
\hline $\begin{array}{l}\text { Het. } \\
\text { class }\end{array}$ & $N$ & $\begin{array}{l}\text { Rank } \\
\text { sum }\end{array}$ & $\begin{array}{l}\text { Rank } \\
\text { mean }\end{array}$ & $\begin{array}{l}\text { Assigned } \\
\text { coefficient }\end{array}$ \\
\hline 0 & 46 & $133 \cdot 0$ & $2 \cdot 891$ & 1 \\
1 & 46 & $136 \cdot 5$ & $2 \cdot 967$ & 2 \\
2 & 46 & $141 \cdot 5$ & $3 \cdot 076$ & 3 \\
3 & 46 & 112.0 & $2 \cdot 435$ & 4 \\
4 & 29 & 82.0 & $2 \cdot 828$ & 5
\end{tabular}

Coefficients assigned to represent the expected ordering of the samples. The agreement between the pattern of coefficients and sample means is non-significant $(P>0 \cdot 10, L=1688.5$, $Z=1 \cdot 410)$. primarily fall into the "+" category: conversely, groups of homozygous fish should fall into the "-" category. In fact, as table 3 shows, there is no evidence of " + " groups predominating in the multiply heterozygous fish, and no evidence of "-" groups predominating in the homozygous fish. No groups within a particular heterozygosity class deviate from a $1: 1$ distribution of "+" and "-.". Thus this analysis also fails to support the hypothesis that multiply heterozygous fish grow more rapidly.

Thirdly, the largest sample (number 20, comprising 689 individuals), collected from Pendine in July 1977, was subjected to special scrutiny and

Table 3 Numbers of groups of fish of specified heterozygosity score with mean lengths longer $(+)$ and shorter $(-)$ than the overall mean length of their sample

\begin{tabular}{llllll}
\hline $\begin{array}{l}\text { Het. } \\
\text { score }\end{array}$ & $N$ & + & - & $X^{2}$ & $P$ \\
\hline 0 & 46 & 22 & 24 & $0 \cdot 043$ & ns \\
1 & 46 & 25 & 21 & $0 \cdot 174$ & ns \\
2 & 46 & 26 & 20 & $0 \cdot 783$ & ns \\
$3+$ & 46 & 19 & 27 & $1 \cdot 391$ & ns \\
\hline
\end{tabular}

$\mathrm{X}^{2}$ tests the hypothesis that frequency of + equals frequency of - . 
analysed using procedures similar to those of Koehn and Gaffney (1984). Individuals ranged in size from 16 to $70 \mathrm{~mm}$, with a mean of 39.75 $(+0.39) \mathrm{mm}$. There is no correlation between length and heterozygosity score (Pearson's $r=$ -0.015 , Spearman's $r=-0.0017, d f=687, P>$ $0.05)$. There is no significant variation in mean length with heterozygosity score (table 4), and the correlation of mean length with heterozygosity is non-significant $(r=-0.210, \quad d f=4, \quad P>0.05)$. Pooling fish with heterozygosity scores of 4 and 5 also produces a non-significant correlation coefficient $(r=0.533, d f=3, P>0.05)$. The variance in growth rate, as measured by the coefficient of variation, is not correlated with heterozygosity ( $r=0.329, d f=4, P>0.05$, or, following pooling, $r=-0.103, d f=3, P>0.05)$.

Table 4 Relationship between heterozygosity score and length in sample 20

\begin{tabular}{lrlll}
\hline $\begin{array}{l}\text { Het. } \\
\text { score }\end{array}$ & $N$ & $\begin{array}{l}\text { Mean } \\
\text { length }\end{array}$ & $S E$ & $C V$ \\
\hline 0 & 105 & $40 \cdot 02$ & 0.94 & $24 \cdot 13$ \\
1 & 273 & $39 \cdot 47$ & 0.64 & 26.95 \\
2 & 213 & $39 \cdot 71$ & 0.67 & 24.44 \\
3 & 75 & $40 \cdot 33$ & 1.36 & $29 \cdot 24$ \\
4 & 21 & $40 \cdot 29$ & 1.95 & 22.78 \\
5 & 2 & $39 \cdot 00$ & 8.0 & 29.01 \\
\hline
\end{tabular}

$r$ for mean length against heterozygosity score $=-0 \cdot 015, \mathrm{df}=4$, n.s.

Next, each fish in this sample was placed into one of 11 size classes, ranging from 15 to $70 \mathrm{~mm}$ in $5 \mathrm{~mm}$ intervals. The mean number of heterozygous loci per fish per interval was determined, as was the mean heterozygosity per fish per interval for each of the five loci. The results are given in table 5 , together with the correlation coefficients between mean length and heterozygosity. It will be seen that there is no significant correlation between multi-locus heterozygosity and length, and of the five single locus tests, only one, that for $\alpha G p d h-1$, proved statistically significant $(0.05>$ $P>0.01)$. This correlation was positive, showing that for this locus, increased growth rate did appear to be associated with increasing heterozygosity. In order to check this finding, the next largest sample (number 19) was analysed in a similar way (table 5). In this instance, the only significant correlation was between multi-locus heterozygosity and length, and this correlation was negative. Thus, the conclusion from these analyses is again that there is no general relationship between heterozygosity and growth rate.
Finally, a reasonable alternative hypothesis to an increase in growth rate with heterozygosity is that fish of intermediate growth rate have the highest heterozygosity. In order to test this hypothesis, the fish analysed in table 4 were separated into three categories, those with decreased growth rates, those with average growth rates, and those with increased growth rates. For each of the two samples, the numbers of heterozygous and homozygous loci in each category were calculated, both for the multi-locus comparison and for each of the five individual loci taken separately. Chi squared tests were performed, first by comparing the numbers of heterozygous and homozygous loci between the three categories of fish (giving $2 \mathrm{df}$ per test), and secondly by pooling fish with increased and decreased growth rates and comparing these fish with fish of intermediate growth rates (giving $1 \mathrm{df}$ per test). The results are given in table 6,24 tests were performed, and two were significant at the 5 per cent level. In sample 19, fish of intermediate growth rate had higher average heterozygosity for $M d h-2$ than other fish, and in sample 20, fish of intermediate growth rate had higher average heterozygosity for $A d a$ than other fish. These deviations from the null hypothesis may be explained through sampling error, and there is thus very little evidence that fish of intermediate growth rate have increased heterozygosity.

\section{DISCUSSION}

The plaice provides an excellent species in which to examine any hypothesised relationships between quantitative traits and enzyme heterozygosity. The Bristol Channel population we have sampled is a very large, randomly mating population, without significant deviations from HardyWeinberg expectations at loci taken singly or in pairs (Ward and McAndrew, 1985), and with little immigration from neighbouring populations (Macer, 1972; note that such populations are in any case likely to be genetically very similar to the Bristol Channel population, Ward and Beardmore, 1977).

No relationship has been found in the plaice between multi-locus heterozygosity and morphological variability, as assayed by caudal, anal, and dorsal fin ray numbers (McAndrew et al., 1982), and the results presented here indicate that there is also no relationship between multi-locus heterozygosity and variability in growth rate. Thus the reduction in growth rate variability with increasing individual heterozygosity observed in 
Table 5 The relationship between size category of fish and multiple and single locus heterozygosity within the two largest samples

\begin{tabular}{|c|c|c|c|c|c|c|c|c|}
\hline \multirow{3}{*}{$\begin{array}{l}\text { Size } \\
\text { category }\end{array}$} & \multirow[b]{3}{*}{$N$} & \multirow{3}{*}{$\begin{array}{l}\text { Mean } \\
\text { length }\end{array}$} & \multicolumn{6}{|c|}{ Mean number of loci heterozygous per fish } \\
\hline & & & \multirow{2}{*}{$\begin{array}{l}\text { Multi } \\
\text { locus }\end{array}$} & \multicolumn{5}{|c|}{ Single locus } \\
\hline & & & & Pgm-1 & Ada & $M d h-2$ & $P g i-1$ & Gpdh-1 \\
\hline \multicolumn{9}{|c|}{ Sample 19, sample size $=248$} \\
\hline $15-20$ & 4 & $19 \cdot 75$ & $1 \cdot 25$ & $0 \cdot 50$ & 0.25 & 0.00 & $0 \cdot 25$ & 0.25 \\
\hline $21-25$ & 19 & $22 \cdot 68$ & $1 \cdot 63$ & $0 \cdot 32$ & 0.58 & 0.37 & $0 \cdot 11$ & $0 \cdot 26$ \\
\hline $26-30$ & 23 & $28 \cdot 61$ & $1 \cdot 48$ & 0.57 & 0.61 & 0.04 & 0.09 & $0 \cdot 17$ \\
\hline $31-35$ & 60 & $33 \cdot 91$ & $1 \cdot 48$ & $0 \cdot 40$ & 0.43 & $0 \cdot 27$ & $0 \cdot 15$ & $0 \cdot 23$ \\
\hline $36-40$ & 63 & $37 \cdot 73$ & $1 \cdot 41$ & 0.43 & 0.44 & $0 \cdot 30$ & $0 \cdot 11$ & $0 \cdot 21$ \\
\hline $41-45$ & 58 & $42 \cdot 52$ & $1 \cdot 28$ & 0.43 & 0.36 & $0 \cdot 16$ & $0 \cdot 14$ & $0 \cdot 19$ \\
\hline $46-50$ & 20 & $47 \cdot 39$ & $1 \cdot 35$ & 0.35 & 0.45 & $0 \cdot 15$ & $0 \cdot 10$ & $0 \cdot 30$ \\
\hline $51-55$ & 1 & $51 \cdot 00$ & $3 \cdot 00$ & $1 \cdot 00$ & $1 \cdot 00$ & 0.00 & $0 \cdot 00$ & $1 \cdot 00$ \\
\hline \multicolumn{9}{|c|}{ Sample 20, sample size $=689$} \\
\hline $15-20$ & 16 & $18 \cdot 94$ & $1 \cdot 69$ & 0.56 & 0.44 & $0 \cdot 25$ & $0 \cdot 25$ & $0 \cdot 19$ \\
\hline $21-25$ & 51 & $23 \cdot 31$ & $1 \cdot 39$ & 0.41 & 0.45 & $0 \cdot 28$ & 0.08 & $0 \cdot 18$ \\
\hline $26-30$ & 70 & $27 \cdot 88$ & $1 \cdot 41$ & 0.40 & 0.41 & $0 \cdot 17$ & $0 \cdot 14$ & 0.29 \\
\hline $31-35$ & 87 & $33 \cdot 14$ & $1 \cdot 47$ & 0.47 & 0.40 & 0.24 & $0 \cdot 10$ & 0.25 \\
\hline $36-40$ & 142 & $38 \cdot 25$ & $1 \cdot 55$ & $0 \cdot 51$ & 0.49 & $0 \cdot 17$ & $0 \cdot 11$ & 0.28 \\
\hline $41-45$ & 135 & $42 \cdot 64$ & 1.47 & 0.39 & 0.47 & 0.21 & 0.23 & 0.19 \\
\hline $46-50$ & 74 & $47 \cdot 74$ & 1.47 & 0.50 & 0.37 & 0.22 & 0.15 & 0.24 \\
\hline $51-55$ & 68 & $52 \cdot 63$ & $1 \cdot 39$ & 0.49 & 0.34 & 0.18 & 0.10 & 0.28 \\
\hline $56-60$ & 26 & $57 \cdot 42$ & $1 \cdot 73$ & 0.42 & 0.50 & 0.42 & 0.08 & 0.31 \\
\hline $61-65$ & 18 & 62.67 & $1 \cdot 60$ & 0.33 & 0.39 & 0.22 & $0 \cdot 22$ & 0.44 \\
\hline $66-70$ & 2 & $69 \cdot 00$ & $1 \cdot 00$ & 0.50 & 0.00 & 0.00 & 0.00 & 0.50 \\
\hline \multicolumn{9}{|c|}{ Pearson correlation coefficients between mean length and heterozygosity: } \\
\hline \multirow{2}{*}{\multicolumn{2}{|c|}{$\begin{array}{l}\text { Sample 19: } \\
\text { Sample 20: }\end{array}$}} & $r, 4 \mathrm{df}$ & $-0.915^{*}$ & $-0 \cdot 117$ & $-0 \cdot 778$ & -0.338 & $0 \cdot 158$ & $0 \cdot 248$ \\
\hline & & $r, 8 \mathrm{df}$, & $0 \cdot 219$ & $-0 \cdot 411$ & $-0 \cdot 195$ & $0 \cdot 184$ & $-0 \cdot 051$ & $0 \cdot 718^{*}$ \\
\hline
\end{tabular}

${ }^{*} P=0.05-0 \cdot 01$

Note: in the calculation of $r$, samples of less than 10 fish were ignored.

Table 6 The relationship between growth rate of fish and multiple and single locus heterozygosity within the two largest samples

\begin{tabular}{|c|c|c|c|c|c|c|c|c|}
\hline \multirow{3}{*}{$\begin{array}{l}\text { Growth } \\
\text { rate }\end{array}$} & \multirow{3}{*}{$\begin{array}{l}\text { Size } \\
\text { category }\end{array}$} & \multirow[b]{3}{*}{$N$} & \multicolumn{6}{|c|}{ Mean number of loci heterozygous per fish } \\
\hline & & & \multirow{2}{*}{$\begin{array}{l}\text { Multi } \\
\text { locus }\end{array}$} & \multicolumn{5}{|c|}{ Single locus } \\
\hline & & & & $P g m-1$ & $A d a$ & $M d h-2$ & $P g i-1$ & Gpdh-1 \\
\hline \multicolumn{9}{|l|}{ Sample 19} \\
\hline A, decreased & $<31 \mathrm{~mm}$ & 46 & $1 \cdot 521$ & 0.457 & 0.565 & $0 \cdot 174$ & $0 \cdot 109$ & $0 \cdot 217$ \\
\hline $\mathrm{B}$, intermediate & $36-40 \mathrm{~mm}$ & 123 & $1 \cdot 488$ & 0.415 & 0.439 & 0.285 & $0 \cdot 130$ & $0 \cdot 220$ \\
\hline$C$, increased & $>40 \mathrm{~mm}$ & 79 & $1 \cdot 316$ & 0.418 & $0 \cdot 392$ & $0 \cdot 152$ & $0 \cdot 127$ & 0.228 \\
\hline$X^{2}, 2 d$ & A v. B v. C & & $1 \cdot 750$ & $0 \cdot 256$ & $3 \cdot 584$ & $5 \cdot 654$ & $0 \cdot 143$ & 0.026 \\
\hline $\mathrm{X}^{2}, 1 \mathrm{~d}$ & B v. $(A+C)$ & & 0.555 & $0 \cdot 077$ & 0.072 & $5 \cdot 573^{*}$ & 0.058 & 0.007 \\
\hline \multicolumn{9}{|c|}{ Sample 20} \\
\hline A, decreased & $<36 \mathrm{~mm}$ & 224 & $1 \cdot 451$ & 0.442 & 0.418 & $0 \cdot 228$ & $0 \cdot 121$ & $0 \cdot 241$ \\
\hline B, intermediate & $36-45 \mathrm{~mm}$ & 277 & 1.513 & 0.451 & 0.477 & $0 \cdot 188$ & $0 \cdot 166$ & 0.231 \\
\hline $\mathrm{C}$, increased & $>45 \mathrm{~mm}$ & 188 & 1.495 & 0.468 & $0 \cdot 372$ & 0.229 & $0 \cdot 138$ & $0 \cdot 287$ \\
\hline \multirow{2}{*}{\multicolumn{3}{|c|}{$\begin{array}{l}\mathrm{X}^{2}, 2 \mathrm{df}, \mathrm{A} v . \mathrm{B} v . \mathrm{C} \\
\mathrm{X}^{2}, 1 \mathrm{df}, \mathrm{B} v \cdot(\mathrm{A}+\mathrm{C})\end{array}$}} & 0.464 & $0 \cdot 286$ & $5 \cdot 096$ & 1.622 & $2 \cdot 148$ & $2 \cdot 017$ \\
\hline & & & $0 \cdot 276$ & 0.004 & $4 \cdot 163^{*}$ & 1.621 & 1.885 & 0.855 \\
\hline
\end{tabular}

$* P=0.05-0.01$ 
the bivalves Crassostrea virginica (Zouros et al., 1980) and Mytilus edulis (Koehn and Gaffney, 1984 ) is not a universal phenomenon.

The major question addressed here is whether multi-locus heterozygosity, as assessed by screening five polymorphic loci, is related to growth rate in the plaice. We find no significant evidence for such a relationship, so the question then becomes one of why we failed to detect such a relationship, when it is apparently so strong in some other species (Mitton and Grant, 1984).

In this paper, length at time $t$ is equated with growth rate. There are two problems with making such an equation. The first is that, as with species examined by other investigators, spawning is spread over a period of time, and thus the fish collected at time $t$ must in reality comprise a range of ages. However, this variation in age relative to the mean age at time $t$ is probably small (and decreases as $t$ increases), and since every collection of fish included a wide range of sizes, it seems likely that age differentiation within a sample accounts for only a small proportion of the size differentiation. The second problem is that we may not be sampling randomly the entire cohort at any given date. In particular, there is a tendency for larger O-group fish to be found in deeper water than smaller fish (Gibson, 1973), and since we were routinely sampling in water less than $1 \mathrm{~m}$ deep, it is likely that the largest, most rapidly growing, fish were under-represented. Thus the mean lengths of our samples, especially for the older fish, are likely to be underestimates of the population means.

Mitton and Grant (1984) suggest that relationships between heterozygosity and growth rate are most likely to be detected in young stages of animals and plants, since such stages put most of their surplus energy into growth with very little being put into reproduction. We have studied plaice from the time they arrive on the nursery beaches, aged about 3 months, to the time they move off into deeper water, a period of about a year. Thus we have restricted ourselves to the examination of young, immature, fish, the stage Mitton and Grant feel would be most likely to reveal such a relationship. Of course, it is possible that heterozygosity and growth rate are related in very young fish ( $<100$ days) or even in older fish (where our samples are very much smaller and do not permit critical testing of the hypothesis), but this is an unsatisfactory conclusion. There are no reasonable grounds for not expecting the relationship to be found in the age range sampled: the fish are growing during the majority of months sampled, especially during the summer when the two largest samples were collected, and at this time competition for food and predator avoidance on the nursery beaches is intense. It is estimated that by the time that metamorphosed fish have reached the nursery beaches, less than 1 per cent of spawned eggs have survived (Harding, 1973), and mortality of " $O$ " group plaice on nursery grounds has been estimated at 50 per cent per month after recruitment is complete (July), gradually dropping to 15 per cent per month by December (Macer, 1967; Steele and Edwards, 1970).

Another explanation for our failure to find significant positive correlations might be that we were simply "unlucky" in our choice of loci, and that had we picked other loci positive correlations might have been forthcoming. Yet this also seems a poor explanation, for in those studies that have reported a positive relationship, and which have partitioned out the effect between loci, virtually all loci analysed, regardless of function, appear to contribute to the trend (Zouros et al., 1980; Green et al., 1983; Koehn and Gaffney, 1984). Furthermore, some of the loci we screened, such as $\mathrm{Pgm}$ and Pgi, are common to many of these surveys.

Perhaps there is no general relationship between multi-locus heterozygosity, at least when assessed from 5 to 10 loci, and growth rate, and those species exhibiting such a relationship are the exception, not the rule. It is well recognised that heterozygosity over half a dozen loci is only very weakly correlated with real individual heterozygosity, measured across the entire genome (Mitton and Pierce, 1980; Chakraborty, 1981), and thus such a general relationship is perhaps not to be expected. So how can the phenomenon be explained in those species exhibiting it? Perhaps only a few loci are concerned in determining growth rate, and by chance some studies happen to sample from this small pool. This seems an unlikely explanation, especially bearing in mind that this pool would have to vary between species, since those studies that have failed to find correlations have loci in common with those giving positive correlations. A second explanation might be that in the latter group of species, heterozygosity at 5 to 10 loci is highly correlated with genomic heterozygosity, perhaps through some aspect of population structure. For example, if the individuals sampled were the progeny of random matings between and within two inbred populations, then the more outbred, more heterozygous, progeny might well grow faster. Cothran et al. (1983) attributed their results on foetal growth rate in deer to such a population structure. Population subdivision will generate heterozygote deficiencies 
through the Wahlund effect, and although such deficiencies were not recorded by Cothran et al., deficiencies have been recorded in some of the species exhibiting positive correlations, such as Crassostrea gigas (Singh and Zouros, 1978) and Mytilus edulis (Koehn and Gaffney, 1984). However, it should be pointed out that such deficiencies are not necessarily the result of population structure, and that several species showing positive correlations do not show deviations from Hardy-Weinberg expectations (e.g., Odocoileus virginianus, Cothran et al., 1983; Mulinia lateralis, Garton et al., 1984; Pinus rigida, Ledig et al., 1983).

Implicit in the hypothesis of a positive correlation between growth rate and heterozygosity, is the notion that increased growth rate is associated with increased fitness. If this were generally true, then directional selection for increased growth rate would be ubiquitous. This seems unlikely, and indeed those individuals growing very rapidly (or very slowly) may well be imbalanced in some physiological way and thus have decreased fitness. Growth rate is a quantitative trait, and in natural populations might be expected to be under stabilising selection.

A clear example of stabilising selection operating on growth rate comes from the classic work of Karn and Penrose (1951, see also Gordon, 1977) on human birth weight: newborn infants of inter- mediate birth weights had higher viabilities than those of more extreme weights. Since, in man at least, birth weight is more dependent on maternal genotype and maternal environment than on foetal genotype (which contributes about 24 per cent of birth weight variance, Robson, 1978), it is likely to be a poor character to use in man (and probably other mammals) in searches for heterozygosity/growth rate correlations. Notwithstanding, Cothran et al. (1983) for deer and Bottini et al. (1979) for man have reported such associations, although a study by Ward et al. (1985) failed to confirm the results of Bottini et al.

Under stabilising selection, and if increasing heterozygosity confers increasing fitness, one might expect individuals of intermediate growth rate to be highly heterozygous. If it is assumed that growth rate in the plaice is subject to stabilising selection, then the results presented in the present paper also fail to support this hypothesis.

To conclude, growth rate in young plaice is not significantly correlated with multi-locus heterozygosity (at 5 loci), nor is it significantly correlated with heterozygosity at the five loci taken individually.

Acknowledgement This work was supported by N.E.R.C. grant GR3/1558 and by the award of a N.E.R.C. research studentship to B. J. McAndrew. We thank Andy Beaumont for comments on an earlier draft of this paper. 


\section{REFERENCES}

BEACHAM, J. D. AND WITHLER, R. E. 1985. Heterozygosity and morphological variability of pink salmon (Oncorhynchus gorbuscha) from southern British Columbia and Puget Sound. Can. J. Genet. Cytol., 27, 571-579.

BEAUMONT, A. R., BEVERIDGE, C. M. AND BUDD, M. D. 1983. Selection and heterozygosity within single families of the mussel Mytilus edulis. (L.) Mar. Biol. Lett., 4, 151-161.

BEAUMONT, A. R. GOSLING, E. M., BEVERIDGE, C. M., BUDD, M. D. AND BURNELL, G. M. In press. Studies on heterozygosity and size in the scallop, Pecten maximus (L.). Proc. 19th European Marine Biology Symposium. Cambridge University Press, pp 443-455.

BOTTINI, E., GLORIA-BOTTINI, F., LUCARELLI, P., POZONETTI, A., SANTORO, F. AND VARVERI, A. 1979. Genetic polymorphisms and intrauterine development: evidence of decreased heterozygosity in light for dates human newborn babies. Experientia, 35, 1565-1567.

CHAKRABORTY, R. 1981. The distribution of the number of heterozygous loci in an individual in natural populations. Genetics, 98, 461-466.

COTHRAN, E. G., CHESSER, R. K., SMITH, M. H. AND JOHNS, P. E. 1983. Influences of genetic variability and maternal factors on fetal growth in white-tailed deer. Evolution, 37, 282-291.

CUSHING, D. H. 1969. The regularity of the spawning season of some fishes. J. Cons. Int. Explor. Mer., 33, 81-92.

DIEHL, W. J. AND KOEHN, R. K. 1985. Multiple-locus heterozygosity, mortality and growth in a cohort of Mytilus edulis. Mar. Biol., 88, 265-271.

FOLTZ, D. W. AND ZOUROS, E. 1984. Enzyme heterozygosity in the scallop Placopecten magellanicus (Gmelin) in relation to age and size. Mar. Biol. Lett., 5, 255-263.

GARTON, D. W., KOEHN, R. K. AND SCOTT, T. M. 1984. Multiplelocus heterozygosity and the physiological energetics of growth in the coot clam, Mulinia lateralis, from a natural population. Genetics, 108, 445-455.

GIBSON, R. N. 1973. The intertidal movements and distribution of young fish on a sandy beach with special reference to the plaice (Pleuronectes platessa L.) J. Exp. Mar. Biol. Ecol., 12, 79-102.

GORDON, R. R. 1977. Premature baby statistics. Br. Med. J., i, 1313-1315.

GRANT, M. C., MITTON, J. B. AND LINHART, Y. B. 1982. Ecological and evolutionary studies of forest trees in Colorado. In Halfpenny J. (ed.) Ecological Studies in the Colorado Alpine: A Festschrift for John W. Marr. Univ. Colo. Occas. Pap. No. 37, pp. 96-100.

GREEN, R. H., SINGH, S. M., HICKS, B. AND McCUIAG, J. 1983. An intertidal population of Macoma balthica (Mollusca, Pelecypoda): genotypic and phenotypic components of population structure. Can. J. Fish. Aquat. Sci., 40, 13601371.

KARN, M. N. AND PENROSE, L. S. 1951. Birthweight and gestation time in relation to maternal age, parity, and infant survival. Ann. Eugen., 15, 206-233.

KING, D. P. F. 1985. Enzyme heterozygosity associated with anatomical character variance and growth in the herring (Clupea harengus L.). Heredity, 54, 289-296.

KNOWLES, P. AND GRANT, M. C. 1981. Genetic patterns associated with growth variability in ponderosa pine. Am. J. Bot. $68,942-946$.

KNOWLES, P. AND MITTON, J. B. 1980. Genetic heterozygosity and radial growth variability in Pinus contorta. Silvae Genet., 29, 114-117.
KOEHN, R. K. AND GAFFNEY, P. M. 1984. Genetic heterozygosity and growth rate in Mytilus edulis. Mar. Biol., 82, 1-7.

LEDIG, F. T., GURIES, R. P. AND BONEFIELD, B. A. 1983. The relation of growth to heterozygosity in pitch pine. Evolution, 37, 1227-1238.

MACER, C. T. 1972. The movements of tagged adult plaice in the Irish Sea. Fish. Investig., London, Ser. 2, 27(6), 41pp.

MEDDIS, R. 1984. Statistics using Ranks: a Unified Approach. Blackwell, Oxford.

MCANDREW, B. J., WARD, R. D. AND BEARDMORE, J. A. 1982. Lack of relationship between morphological variance and enzyme heterozygosity in the plaice, Pleuronectes platessa. Heredity, 48, 117-125.

MitToN, J. B. 1983. Conifers. In Tanksley, S. and Orton, T. (eds.) Isozymes in Plant Genetics and Breeding, Part B. Elsevier, Amsterdam, pp. 443-472.

MITTON, J. B. AND GRANT, M. C. 1980. Observations on the ecology and evolution of quaking aspen, Populus tremuloides, in the Colorado Front Range. Am. J. Bot. 67, 202-209.

MITTON, J. B. AND GRANT, M. C. 1984. Associations among protein heterozygosity, growth rate, and developmental homeostasis. Ann. Rev. Ecol. Syst., 15, 479-499.

MITTON, J. B. AND PIERCE, B. A. 1980. The distribution of individual heterozygosity in natural populations. Genetics, 95, 1043-1054.

MITTON, J. B., KNOWLES, P., STURGEON, K. B., LINHART, Y. B. AND DAVIS, M. 1981. Associations between heterozygosity and growth rate variables in three western forest trees. In Conkle, M. T. (ed.) Proc. Symp. Isozymes North Am. For. Trees and For. Insects, US Dep. Agric. Gen. Tech. Rep. PSW-48, U.S.G.P.O., Washington, D.C., pp. 27-34.

NIE, N. H., HULL, C. H., JENKINS, J. G., STEINBRENNER, K. AND BENT, D. H. 1975. Statistical Package for the Social Sciences, 2nd ed., McGraw Hill, New York.

PIERCE, B. A. AND MITTON, J. B. 1982. Allozyme heterozygosity and growth in the tiger salamander, Ambystoma tigrinum. J. Hered., 73, 250-253.

ROBSON, E. B. 1978. The genetics of birth weight. In Falkner, F. and Tanner, J. M. (eds.) Human Growth, Vol. 1: Principles and prenatal growth. Bailliere, Tindall, London, pp. 249-297.

SIMPSON, A. C. 1959. The spawning of plaice (Pleuronectes platessa) in the Irish Sea. Fish. Investig., London, Ser. 2, 22(8), 30pp.

SINGH, S. M. AND ZOUROS, E. 1978. Genetic variation associated with growth rate in the American oyster (Crassostrea virginica). Evolution, 32, 342-353.

STEELE, J. H. AND EDWARDS, R. R. C. 1970. The ecology of O-group plaice and common dab in Loch Ewe. IV. The dynamics of plaice populations. J. Exp. Mar. biol. Ecol., 4, 174-187.

WARD, R. D. AND BEARDMORE, J. A. 1977. Protein variation in the plaice, Pleuronectes platessa L. Genet. Res., 30, 45-62.

WARD, R. D. AND McANDREW, B. J. 1985. A search for gametic disequilibrium in the plaice, Pleuronectes platessa. Heredity, $55,105-110$.

WARD, R. D., SARFARAZI, M., AZIMI-GARAKANI, C. AND BEARDMORE, J. A. 1985. Population genetics of polymorphisms in Cardiff newborn: relationship between blood group and allozyme heterozygosity and birth weight. Hum. Hered., 35, 171-177.

zoUROS, E., SINGH, S. M. AND MILES, H. E. 1980. Growth rate in oysters: an overdominant phenotype and its possible explanations. Evolution, 34, 856-867. 


\section{APPENDIX}

Mean lengths of fish with heterozygosity scores of 0 to 5 in each of the samples.

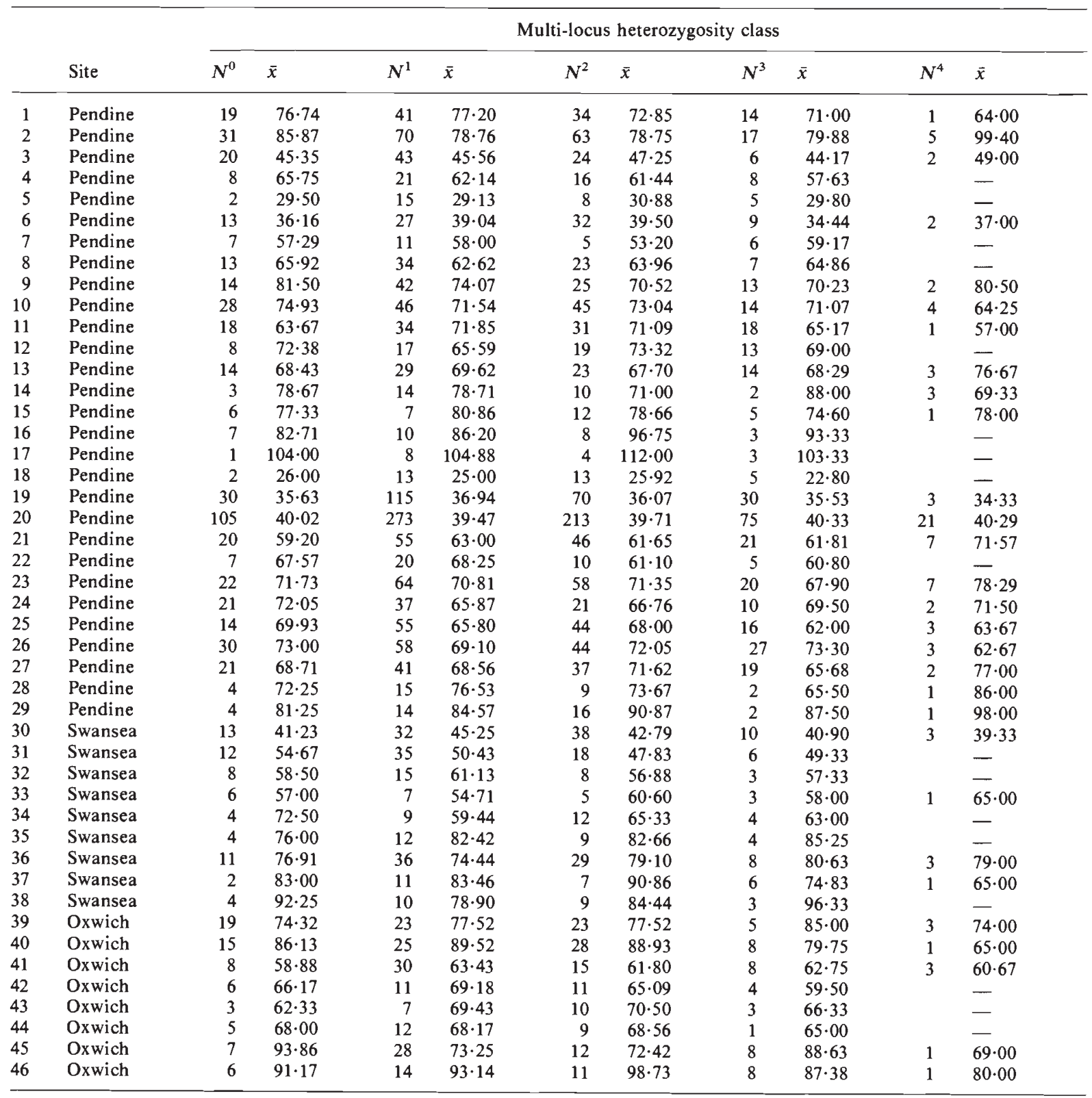

Three samples had fish with 5 heterozygous loci:

sample $20, N=2, \bar{x}=39 \cdot 00$;

sample $40, N=1, x=109$;

sample $41, N=1, x=75$, 